\title{
Effect of feeding warm-season annuals with orchardgrass on ruminal fermentation and methane output in continuous culture
}

\author{
S. L. Dillard, ${ }^{*}$ A. N. Hafla, ${ }^{*}$ A. I. Roca-Fernández, ${ }^{*} \dagger$ A. F. Brito,ł M. D. Rubano, ${ }^{*}$ and K. J. Soder ${ }^{* 1}$ \\ *Pasture Systems and Watershed Management Research Unit, USDA-Agricultural Research Service, University Park, PA $16802-3702$ \\ †Depto. Producción Vegetal, Escuela Politécnica Superior, Universidad de Santiago de Compostela, Lugo, España 27002 \\ ‡Department of Biological Sciences, University of New Hampshire, Durham 03824
}

\section{ABSTRACT}

A 4-unit, dual-flow continuous culture fermentor system was used to assess nutrient digestibility, volatile fatty acids (VFA) production, bacterial protein synthesis, and methane $\left(\mathrm{CH}_{4}\right)$ output of warm-season annual grasses. Treatments were randomly assigned to fermentors in a $4 \times 4$ Latin square design using $7 \mathrm{~d}$ for adaptation to treatment and $3 \mathrm{~d}$ for sample collection. Treatments were (1) $100 \%$ orchardgrass (Dactylis glomerata L.; ORD); (2) 50\% orchardgrass $+50 \%$ Japanese millet [Echinochloa esculenta (A. Braun) H. Scholz; MIL]; (3) $50 \%$ orchardgrass $+50 \%$ brown midrib sorghum $\times$ sudangrass (Sorghum bicolor L. Moench $\times$ S. bicolor var. sudanense; $\mathrm{SSG}]$; or (4) $50 \%$ orchardgrass $+25 \%$ millet $+25 \%$ sorghum $\times$ sudangrass (MIX). Fermentors were fed $60 \mathrm{~g}$ of dry matter $(\mathrm{DM}) / \mathrm{d}$ in equal portions of herbage 4 times daily $(0730,1030,1400$, and $1900 \mathrm{~h}$ ). To replicate a typical 12 -h pasture rotation, fermentors were fed the orchardgrass at 0730 and $1030 \mathrm{~h}$ and the individual treatment herbage (orchardgrass, Japanese millet, sorghum $\times$ sudangrass, or 50:50 Japanese millet and sorghum $\times$ sudangrass) at 1400 and $1900 \mathrm{~h}$. Gas samples for $\mathrm{CH}_{4}$ analysis were collected 6 times daily at $0725,0900,1000,1355,1530$, and 1630 h. Fermentor $\mathrm{pH}$ was determined at the time of feeding, and fermentor effluent samples for $\mathrm{NH}_{3} \mathrm{~N}$ and VFA analyses were taken daily at $1030 \mathrm{~h}$ on $\mathrm{d} 8,9$, and 10. Samples were also analyzed for DM, organic matter (OM), crude protein, and fiber fractions to determine nutrient digestibilities. Bacterial efficiency was estimated by dividing bacterial $\mathrm{N}$ by truly digested OM. True DM and OM digestibilities and $\mathrm{pH}$ were not different among treatments. Apparent OM digestibility was greater in ORD than in MIL and SSG. The concentration of propionate

Received May 25, 2016.

Accepted October 8, 2016.

${ }^{1}$ Corresponding author: Kathy.Soder@ars.usda.gov was greater in ORD than in SSG and MIX, and that of butyrate was greatest in ORD and MIL. Methane output was greatest in MIL, intermediate in ORD, and lowest in SSG and MIX. Nitrogen intake did not differ across treatments, whereas bacterial $\mathrm{N}$ efficiency per kilogram of truly digestible OM was greatest in MIL, intermediate in SSG and MIX, and lowest in ORD. True crude protein digestibility was greater in ORD versus MIL, and ORD had lower total $\mathrm{N}$, non- $\mathrm{NH}_{3}-\mathrm{N}$, bacterial $\mathrm{N}$, and dietary $\mathrm{N}$ in effluent flows than MIL. Overall, we detected little difference in true nutrient digestibility; however, SSG and MIX provided the lowest acetate to propionate ratio and lower $\mathrm{CH}_{4}$ output than MIL and ORD. Thus, improved warm-season annual pastures (i.e., brown midrib sorghum $\times$ sudangrass) could provide a reasonable alternative to orchardgrass pastures during the summer months when such perennial cool-season grass species have greatly reduced productivity.

Key words: continuous culture, ruminal fermentation, warm-season annual

\section{INTRODUCTION}

Perennial cool-season grasses provide high-quality forage for pasture-based dairy systems in the temperate regions of the United States throughout the spring and fall grazing seasons. However, forage production and quality decline markedly during the hot summer months (July and August), an occurrence frequently referred to as the "summer forage slump." Winsten et al. (2010) reported that, of 987 dairy farms surveyed across the northeastern United States, $13 \%$ used management-intensive rotational grazing and $80 \%$ of farms used a combination of low-intensity grazing and traditional confinement systems. According to Stiglbauer et al. (2013), 85 and $95 \%$ of the conventional pasturebased and organic-certified dairies, respectively, used management-intensive rotational grazing across New York, Wisconsin, and Oregon. With the number of pasture-based dairies expected to increase as a result 
of increasing demand for grass-fed and organic milk (Pereira et al., 2013), a requirement for pasture-based diets with some milk processors (e.g., certified organic labels through USDA-National Organic Program or labels through individual processors), and some climate models predicting warmer, drier summers for temperate regions during the next century (Wolfe et al., 2008), evaluation of heat- and drought-tolerant warm-season forages that can support profitable milk production in pasture-based dairy cattle is paramount.

Warm-season annuals such as sorghum, sudangrass, sorghum $\times$ sudangrass hybrids, and millets have been promoted as highly productive forages, but are considered to be highly lignified and have low leaf-to-stem ratios, resulting in lower-quality forage and reduced digestibility compared with perennial cool-season forages (Cowan and Lowe, 1998). Research in the northeastern United States reported that brown midrib (BMR) sorghum $\times$ sudangrass yielded $7,297 \mathrm{~kg}(\mathrm{DM}) / \mathrm{ha}$ and contained $12.9 \% \mathrm{CP}$ and $61.7 \% \mathrm{NDF}$, with the NDF reported to be $77.5 \%$ digestible (Ketterings et al., 2005). Using a prediction model (Milk2000; http://www.uwex $\mathrm{edu} / \mathrm{ces} /$ forage/pubs/milk2000.xls), the estimated milk production was $1,552 \mathrm{~kg}$ of milk/Mg of forage DM and $11,301 \mathrm{~kg}$ of milk/ha. However, this model does not consider air temperature, which can have a negative effect on DMI and milk production when temperatures exceed $20^{\circ} \mathrm{C}$ (NRC, 2001). Fontaneli et al. (2001) observed that intensively managed warm-season annuals grown in a subtropical climate were of sufficient yield and quality $(5.7 \mathrm{Mg}$ of $\mathrm{DM} / \mathrm{ha}, 18.3 \% \mathrm{CP}$, and $61.6 \%$ in vitro $\mathrm{OM}$ digestibility to meet the nutritional demands of lactating dairy cows producing $20 \mathrm{~kg}$ of milk/d; NRC, 2001). Fontaneli et al. (2001) also stated that warm-season annuals would significantly contribute to the development of a year-round, grazing dairy system. However, there is currently no literature available on the performance of lactating dairy cows consuming warm-season annuals compared with perennial, coolseason forage.

Even though it has been considered standard practice to include warm-season annuals in the forage program of pasture-based dairy farms in temperate regions such as the northeastern United States since the 1960s (Clark et al., 1965), only limited information is available on the digestibility and animal production potential of warm-season annuals when used in the diet of lactating dairy cows. Furthermore, new varieties (e.g., BMR) have been developed that could prove to be of superior nutritional quality compared with older varieties of warm-season annuals (Ketterings et al., 2005). Therefore, the objective of the current study was to determine the effects of Japanese millet, BMR sorghum $\times$ sudangrass, and a mixture of both on nutrient digest- ibility, VFA production, bacterial protein synthesis and methane $\left(\mathrm{CH}_{4}\right)$ output in continuous culture compared with a typical, cool-season herbage (i.e., orchardgrass). We hypothesized that inclusion of the warm-season annual forages will provide greater digestible OM compared with orchardgrass alone, resulting in improved ruminal fermentation and decreased $\mathrm{CH}_{4}$ production per unit of OM digested.

\section{MATERIALS AND METHODS}

\section{Site, Experimental Design, and Herbage Treatments}

The study was conducted at the USDA-Agricultural Research Service Pasture Systems and Watershed Management Research Unit (University Park, PA) from February to April 2015. On June 16, 2014, FSG 208 BMR (Seedway LLC, Hall, NY) hybrid sorghum $\times$ sudangrass (Sorghum bicolor L. Moench $\times$ S. bicolor var. sudanense) and Japanese millet [Echinochloa esculenta (A. Braun) H. Scholz] were planted into a prepared seedbed using a no-till drill (HEGE 1000; Wintersteiger AG, Waldenburg, Germany). Plots were fertilized with $46 \mathrm{~kg}$ of $\mathrm{N} / \mathrm{ha}$ in a split-application using ammonium sulfate; $\mathrm{P}$ and $\mathrm{K}$ were applied to plots according to soil test results. Plots were harvested twice during the growing season (July 17 and September 23, 2014), when herbage height was within the optimal range for grazing (45 to $75 \mathrm{~cm}$; Hodgson et al., 1977). Orchardgrass (Dactylis glomerata L.) was harvested in the morning of July 2 and September 23, 2014, from a 1-yr-old pure stand. Orchardgrass was harvested in a vegetative stage of growth, typical of high-quality pastures used for grazing in temperate regions of the United States (25 to $30 \mathrm{~cm}$ tall). A plot harvester (HEGE 212; Wintersteiger AG; 1.5-m-wide swath), set to a $10-\mathrm{cm}$ stubble height was used to harvest all plots. Within $30 \mathrm{~min}$ of harvest, herbage was placed in cloth bags and frozen $\left(-4^{\circ} \mathrm{C}\right)$ until being freeze-dried (Ultra 35 Super ES; Virtis Co. Inc., Gardiner, NY). Freeze-dried herbage was ground to pass through a 2-mm sieve (Wiley mill; Thomson Scientific Inc., Philadelphia, PA) to be used as feed for the fermentors. Although we recognize that freeze-dried forages are not nutritionally identical to fresh forages, the herbage needed to be preserved and ground for use in this experiment, and Jones and Bailey (1972) reported that oven-drying forages could denature protein in plant material and depress digestibility.

Total DM fed to all fermentors was maintained at a constant $60 \mathrm{~g} / \mathrm{d}$ for the duration of each period. Treatments were as follows: (1) 100\% orchardgrass (ORD); (2) $50 \%$ orchardgrass $+50 \%$ Japanese millet (MIL); (3) $50 \%$ orchardgrass $+50 \%$ sorghum $\times$ sudangrass (SSG); or (4) $50 \%$ orchardgrass $+25 \%$ Japanese millet 
Table 1. Chemical composition (\% of DM unless otherwise noted) of orchardgrass and orchardgrass/warm-season annual mixtures fed during continuous culture fermentation

\begin{tabular}{|c|c|c|c|c|c|c|c|}
\hline \multirow[b]{2}{*}{ Item } & \multicolumn{3}{|c|}{ Ingredient } & \multicolumn{4}{|c|}{ Treatment $^{1}$} \\
\hline & Orchardgrass & Japanese millet & Sorghum $\times$ sudangrass & ORD & MIL & SSG & MIX \\
\hline $\mathrm{CP}$ & 17.9 & 17.8 & 17.8 & 17.9 & 17.9 & 17.9 & 17.9 \\
\hline RDP, $\%$ of $\mathrm{CP}$ & 73.0 & 71.0 & 80.0 & 73.0 & 72.0 & 76.5 & 74.3 \\
\hline $\mathrm{NDF}$ & 59.2 & 49.2 & 54.0 & 59.2 & 54.2 & 56.6 & 55.4 \\
\hline $\mathrm{ADF}$ & 37.4 & 30.7 & 34.5 & 37.4 & 34.1 & 34.5 & 35.0 \\
\hline $\mathrm{ESC}^{4}$ & 6.3 & 6.4 & 11.9 & 6.3 & 6.4 & 9.1 & 7.7 \\
\hline CP:NFC & 1.49 & 0.89 & 1.02 & 1.49 & 1.19 & 1.25 & 1.22 \\
\hline Starch & 1.6 & 9.2 & 1.3 & 1.6 & 5.4 & 1.5 & 3.4 \\
\hline $\mathrm{NSC}^{5}$ & 10.9 & 10.1 & 2.3 & 10.9 & 14.6 & 13.1 & 13.8 \\
\hline $\mathrm{NE}_{\mathrm{L}},{ }^{6} \mathrm{Mcal} / \mathrm{kg}$ & 1.23 & 1.39 & 1.30 & 1.23 & 1.32 & 1.28 & 1.30 \\
\hline $\mathrm{Ca}$ & 0.37 & 0.46 & 0.30 & 0.37 & 0.42 & 0.34 & 0.38 \\
\hline $\mathrm{P}$ & 0.24 & 0.26 & 0.24 & 0.24 & 0.25 & 0.24 & 0.25 \\
\hline
\end{tabular}

${ }^{1}$ Calculated using actual nutrient composition and proportion of individual ingredients (DM basis); ORD $=100 \%$ orchardgrass; MIL $=50 \%$ orchardgrass $+50 \%$ Japanese millet; SSG $=50 \%$ orchardgrass $+50 \%$ sorghum $\times$ sudangrass; MIX $=50 \%$ orchardgrass $+25 \%$ Japanese millet $+25 \%$ sorghum $\times$ sudangrass.

${ }^{2}$ Calculated as NFC $=100-(\mathrm{CP} \%+\mathrm{NDF} \%+$ ether extract $\%+$ ash $\%)$.

${ }^{3} \mathrm{WSC}=$ water-soluble carbohydrate.

${ }^{4} \mathrm{ESC}=$ ethanol-soluble carbohydrate.

${ }^{5} \mathrm{NSC}=\mathrm{WSC}+$ starch.

${ }^{6}$ Estimated by the NRC (2001) model.

$+25 \%$ sorghum $\times$ sudangrass (MIX). Fermentors were fed equal portions of herbage 4 times daily $(0730,1030$, 1400, and $1900 \mathrm{~h}$ ). All fermentors were fed orchardgrass at 0730 and $1030 \mathrm{~h}$ and the individual treatment herbage (orchardgrass, Japanese millet, sorghum $\times$ sudangrass, or 50:50 Japanese millet and sorghum $\times$ sudangrass) at 1400 and $1900 \mathrm{~h}$. The feeding schedule was designed to mimic grazing patterns of dairy cattle, including a fresh allotment of pasture (in this case, warm-season annuals) after milking (Hoffman et al., 2000). Representative samples of freeze-dried herbage were collected from each treatment at the beginning of the study for nutrient analyses at a commercial laboratory (Dairy One Laboratories, Ithaca, NY; Table 1).

\section{Continuous Culture System and Operation}

The study was conducted as a $4 \times 4$ Latin square design. Treatments were incubated in a 4-unit, dualflow continuous culture fermentor system (OmniCulture Plus; VirTis Co. Inc.) similar to that described by Hoover et al. (1989), with the following modifications: $\mathrm{pH}$ was not controlled, feed ingredients were not pelleted, fermentor volumes ranged from 1.10 to 1.14 $\mathrm{L}$, urea was added to the mineral buffer solution at a rate of $0.4 \mathrm{~g} / \mathrm{L}$ to simulate recycled $\mathrm{N}$ (Weller and
Pilgrim, 1974), and fermentors were continually stirred at $255 \mathrm{rpm}$ (Soder et al., 2016). Solid mean retention time, solid dilution rate, and liquid dilution rate of the fermentors were adjusted daily to approximately $24 \mathrm{~h}$, $4.17 \% / \mathrm{h}$, and $11 \% / \mathrm{h}$, respectively, which was achieved by regulation of buffer input and filtrate removal (pore size $=104.14 \mu \mathrm{m}$; Hoover et al., 1976).

Ruminal fluid and digesta samples were collected from a ruminally fistulated, nonlactating, multiparous Holstein cow $(\mathrm{BW}=652 \mathrm{~kg})$ cared for in accordance with the Pennsylvania State University Animal Care and Use (IACUC \#39513) guidelines. The donor cow was group housed and fed a diet of mixed grain and grass hay (35:65 concentrate-to-forage ratio) in a feed bunk for a total of $16.2 \mathrm{~kg}$ (DM) of available feed per cow per day at the Pennsylvania State University Dairy Research Farm (University Park). A vitamin-mineral premix was included to meet NRC (2001) recommendations and was fed at $1.8 \%$ of total DMI. Approximately $3 \mathrm{~h}$ after feeding, $6 \mathrm{~L}$ of ruminal fluid was collected with a hand pump into a prewarmed insulated container and maintained at $39^{\circ} \mathrm{C}$. Solid digesta was collected by hand from the ventral, central, and dorsal areas of the rumen. Liquid and whole digesta samples were transported to the USDA laboratory in separate containers. Within 15 min of collection, fluid was strained through 4 layers of 
cheesecloth and poured into each of the prewarmed fermentation jars until it cleared the overflow spout. Solid digesta was mixed by hand and $25 \mathrm{~g}$ was added to each fermentor. Each fermentor was continuously purged with $\mathrm{CO}_{2}$ gas at a rate of $20 \mathrm{~mL} / \mathrm{min}$ (model MC50; Alicat Scientific, Tucson, AZ) to maintain anaerobiosis, and the temperature was maintained at $39^{\circ} \mathrm{C}$. Fermentor $\mathrm{pH}$ was recorded manually immediately before each of the 4 daily feedings.

Fermentors were operated for 4 consecutive 10-d periods according to the methods of Soder et al. (2016). In brief, each period consisted of a 7 -d adaptation period followed by a 3 -d sampling period. During the adaptation period, liquid and solid overflow were collected daily, weighed, and then discarded. After being emptied on d 7 and continuing through d 10, liquid and solid overflow containers were chilled in a $4^{\circ} \mathrm{C}$ water bath and each received $20 \mathrm{~mL}$ of $50 \% \mathrm{H}_{2} \mathrm{SO}_{4}$ (vol/vol) daily before overflow collection. During the last $3 \mathrm{~d}$ of each period, liquid and solid effluent overflows from each fermentor were combined and mixed. After mixing, a 100-mL effluent sample was taken and composited over the $3 \mathrm{~d}$ to determine overflow DM. A 50-mL sample of effluent was strained through 8 layers of cheesecloth and a subsample taken for VFA (Erwin et al., 1961) and $\mathrm{NH}_{3}-\mathrm{N}$ analyses using the methods of Chaney and Marbach (1962). An additional 1.10L sample of 3-d composited effluent was freeze-dried, ground to pass through a 1-mm sieve, and analyzed for DM, OM, NDF, and CP (AOAC International, 2006), and total purines (Zinn and Owens, 1986). During the last day of each period, the contents of each fermentor were mixed, strained through 2 layers of a $53-\mu \mathrm{m}$ Nitex fabric (Wildco, Buffalo, NY), combined with $5 \mathrm{~mL}$ of $50 \% \mathrm{H}_{2} \mathrm{SO}_{4}$ ( $\left.\mathrm{vol} / \mathrm{vol}\right)$, and centrifuged 3 times at 20,000 $\times g$ for $20 \mathrm{~min}$ at $-4^{\circ} \mathrm{C}$ with the pellet resuspended in $0.9 \%$ saline (wt/vol) and $50 \%$ methanol ( $\mathrm{vol} / \mathrm{vol})$, respectively, for the last 2 centrifugations (Griswold et al., 1996). The final pellet was freeze-dried and analyses for DM, OM, CP (AOAC International, 2006), and total purines (Zinn and Owens, 1986) were completed and used to calculate nutrient digestibility, bacterial protein synthesis, and N metabolism (Soder et al., 2016).

\section{Gas Collection and Measurements}

Gas samples for $\mathrm{CH}_{4}$ analysis were collected 6 times daily in duplicate $(0725,0900,1000,1355,1530$, and $1630 \mathrm{~h}$ ) using a 25-gauge needle attached to a $30-\mathrm{mL}$ syringe (Vibart et al., 2007). Ten minutes before gas collection, a rubber stopper (size 1) was placed in the effluent overflow port to prevent gas escape. After the syringe was plunged 3 times to purge any residual gas, the needle was inserted through a rubber septum (part
\#608010; Sigma-Aldrich, St. Louis, MO) located in a port on top of the fermentor, and $30 \mathrm{~mL}$ of gas was withdrawn from the headspace. A stopcock attached between the needle and syringe ensured that gas did not escape upon transference to an evacuated $15-\mathrm{mL}$ glass vial through a septum in the cap. Gas samples were analyzed for $\mathrm{CH}_{4}$ using GC (Varian CP 3800; Agilent Technologies, Santa Clara, CA) as described in Soder et al. (2012). A separate needle and syringe were designated for each fermentor. Estimates of daily $\mathrm{CH}_{4}$ output $(\mathrm{mmol} / \mathrm{d})$ were calculated using the following equation: $\mathrm{CH}_{4}$ concentration in fermentor headspace $(\mathrm{mmol} / \mathrm{L}) \times \mathrm{CO}_{2}$ gas flow through the fermentor headspace $(20 \mathrm{~mL} / \mathrm{min}) \times 60 \mathrm{~min} \times 24 \mathrm{~h}$ (Johnson et al., 2009).

\section{Nutrient Analyses}

Samples of orchardgrass, Japanese millet, and sorghum $\times$ sudangrass were analyzed by wet chemistry (Dairy One Laboratories, Ithaca, NY) according to the following procedures: DM (method 930.15; AOAC International, 2006), CP (method 990.03; AOAC International, 2006), RDP (Cornell Streptomyces griseus enzymatic digestion; Coblentz et al., 1999), NDF [Ankom model A200; Mertens (2002), with heat-stable $\alpha$-amylase and sodium sulfite used in the NDF procedure (inclusive of ash)]. Water-soluble carbohydrates (WSC) were determined by incubating samples in a $40^{\circ} \mathrm{C}$ water bath for $1 \mathrm{~h}$, extracting WSC (simple sugars and fructans). The WSC were determined using a Thermo Scientific Genesys 10S Vis Spectrophotometer after acid hydrolysis with $\mathrm{H}_{2} \mathrm{SO}_{4}$ (Smith, 1969) using potassium ferricyanide for the colorimetric reaction rather than potassium iodide-potassium oxalate as cited in Smith (1969), as potassium ferricyanide provides a more stable reaction for detecting reducing sugars (Miller-Webster et al., 2002). Ethanol-soluble carbohydrates (Hall et al., 1999), starch (Application Note Number 319; YSI Inc. Life Sciences, Yellow Springs, $\mathrm{OH}$ ), minerals (Ca, P, Mg, K, Na; Thermo IRIS Advantage HX or intrepid inductively coupled plasma radial spectrometer after microwave digestion; CEM Application Note for Acid Digestion, CEM Corp., Matthews, NC), and ether extract (method 2003.05; AOAC International, 2006) were also determined. The NFC concentration was calculated using the equation NFC $(\%)=100 \%-(\mathrm{CP} \%+\mathrm{NDF} \%+$ ether extract $\%+$ ash \%). Pectins were included in the NFC calculation but not included in WSC or NSC analyses.

Effluent samples were analyzed for DM and OM (methods 930.15 and 942.05, respectively; AOAC International, 2006) and CP concentrations (micro-Kjeldahl digestion using $75-\mathrm{mL}$ calibrated tubes with $\mathrm{CuSO}_{4} /$ 
$\mathrm{K}_{2} \mathrm{SO}_{4}$ catalyst, method 976.06; AOAC International, 2006). The NDF concentration of the effluent was determined as done for herbage NDF reported above. Concentrations of total purines (Zinn and Owens, 1986) in effluent and bacterial isolates were used to partition effluent $\mathrm{N}$ flow into bacterial and nonbacterial fractions and to calculate true DM and OM digestibilities and flows.

\section{Statistical Analysis}

Data were analyzed as a $4 \times 4$ Latin square design using the PROC MIXED procedure of SAS (SAS Inst. Inc., Cary, NC), fitted to the following model:

$$
\mathrm{Y}_{i j k}=\mu+\mathrm{P}_{i}+\mathrm{F}_{j}+\mathrm{T}_{k}+\mathrm{e}_{i j k}
$$

where $Y_{i j k}=$ observations for dependent variables, $\mu$ $=$ population mean, $\mathrm{P}_{i}=$ mean effect of $i$ th period, $\mathrm{F}_{j}$ $=$ mean effect of $j$ th fermentor, $\mathrm{T}_{k}=$ mean effect of $k$ th treatment, and $\mathrm{e}_{i j k}=$ residual error. Treatment was considered a fixed effect, and fermentor, period, and error were random effects.

Measures of $\mathrm{CH}_{4}$ concentrations were analyzed for temporal patterns using the following model:

$$
\mathrm{Y}_{i j k l}=\mu+\mathrm{P}_{i}+\mathrm{F}_{j}+\mathrm{T}_{k}+\mathrm{E} 1_{i j k}+\mathrm{H}_{l}+\mathrm{HT}_{l k}+\mathrm{E} 2_{i j k l},
$$

where $\mathrm{Y}_{i j k l}=$ observations for dependent variables, $\mu=$ population mean, $\mathrm{P}_{i}=$ mean effect of $i$ th period, $\mathrm{F}_{j}=$ mean effect of $j$ th fermentor, $\mathrm{T}_{k}=$ mean effect of $k$ th treatment, $\mathrm{E} 1_{i j k}=$ whole-plot error, $\mathrm{H}_{l}=$ mean effect of $l$ th hour sampled analyzed as repeated measures, $\mathrm{HT}_{l k}=$ interaction between lth hour and $k$ th treatment, and $\mathrm{E} 2_{i j k l}=$ subplot residual error. Treatment, hour sampled, and their interaction were considered fixed effects, and period, fermentor, whole-plot error, and subplot error were considered random. A first-order autoregressive covariance structure, which showed the lowest Akaike information criterion values, was retained in the final model. Least squares means were compared by least squared minimum difference. Pearson correlation coefficients between $\mathrm{N}$ metabolism variables and forage characteristics were conducted according to the PROC CORR procedure of SAS, and stepwise linear regression analysis was conducted according to the PROC REG procedure of SAS to detect predictive statistical associations between forage characteristics and $\mathrm{N}$ metabolism metrics. For all statistical analyses, significance was declared at $P \leq 0.05$ and tendencies at $0.05<P \leq 0.10$. Apparent (DM, OM, NDF, and ADF) and true (DM, OM, and $\mathrm{CP}$ ) digestibilities of nutrients were calculated according to equations from Soder et al. (2016).

\section{RESULTS AND DISCUSSION}

\section{Treatment Composition}

The chemical composition of dietary ingredients and treatments are presented in Table 1. Statistical comparison of treatments was not conducted because treatment nutrient compositions were based on pooled samples. The nutritive value of orchardgrass in the current study was similar to that reported by Hafla et al. (2016). The CP, ADF, and mineral concentrations of Japanese millet were similar to previous literature reports (Muldoon, 1985; Darby et al., 2016). Similarly, the CP, fiber fractions, and mineral concentrations of the sorghum $\times$ sudangrass were similar to those in previous studies (Fontaneli et al., 2001; Ketterings et al., 2005). Overall, the nutrient concentration of the treatments used in the current study was considered to be of moderate quality with $\mathrm{CP}$ of $18 \%$ and a moderately high NDF concentration of 55 to $60 \%$ (Bargo et al., 2003). The OM, CP, and $\mathrm{NE}_{\mathrm{L}}$ of all treatments were numerically similar. The NDF and ADF concentrations were numerically greater in ORD than in the warmseason annual treatments (MIL, SSG, and MIX). Concentrations of WSC and ethanol-soluble carbohydrate were numerically greater (20 and $30 \%$, respectively) in SSG than in ORD and MIL; conversely, starch was $69 \%$ numerically greater in MIL than in SSG and ORD. The $\mathrm{CP}$ to NFC ratio was numerically greater in ORD than in any other treatment, and MIL had the numerically lowest ratio.

\section{Nutrient Digestibility}

We detected no effect $(P \geq 0.11)$ of treatment on apparent digestibilities of $\mathrm{DM}, \mathrm{NDF}$, and $\mathrm{ADF}$, or on true digestibilities of DM and OM (57.0, 80.1, 78.4, 70.4 , and $76.4 \%$, respectively; Table 2 ). The apparent OM digestibility was 14 and $9.7 \%$ greater in ORD than in MIL $(P=0.01)$ and SSG $(P=0.04)$, respectively. Apparent OM digestibility also tended $(P=0.06)$ to be greater in ORD than in MIX.

Apparent and true OM digestibilities of ORD were similar to that observed by Soder et al. (2012); however, apparent and true DM digestibilities in the current study were 25 and $19 \%$ lower, respectively, and apparent NDF digestibility was $9 \%$ greater than that in Soder et al. (2012). Conversely, true DM and OM digestibilities of ORD in the current study were 39 and $53 \%$ greater, respectively, than a $50 \%$ orchardgrass, $25 \%$ red clover (Trifolium pratense L.), and $25 \%$ alfalfa (Medicago sativa L.) pasture mixture (Bach et al., 1999). Other studies reported digestible DM of 48.6 to $51.6 \%$ for pure Japanese millet and sorghum $\times$ sudangrass 
Table 2. Nutrient digestibility of orchardgrass and orchardgrass/warm-season annual mixtures fed during continuous culture fermentation

\begin{tabular}{llllll}
\hline & \multicolumn{5}{c}{ Treatment $^{1}$} \\
\cline { 2 - 4 } Item & ORD & MIL & SSG & MIX & \multirow{2}{*}{ SEM } \\
\hline Apparent digestibility & & & & \\
DM, \% & 56.0 & 55.5 & 57.5 & 58.8 & 3.03 \\
OM, \% & $71.1^{\mathrm{a}}$ & $62.3^{\mathrm{b}}$ & $64.8^{\mathrm{b}}$ & $65.0^{\text {ab }}$ & 2.36 \\
NDF, \% & 84.8 & 75.6 & 76.0 & 83.9 & 3.08 \\
ADF, \% & 80.2 & 78.4 & 76.5 & 78.5 & 2.39 \\
True digestibility & & & & 73.1 & 4.10 \\
DM, \% & 67.8 & 70.6 & 70.2 & 76.4 & 2.49 \\
OM, \% & 80.2 & 74.1 & 75.0 & 76.0 \\
\hline
\end{tabular}

${ }^{\mathrm{a}, \mathrm{b}}$ Within a row, means without a common superscript differ $(P \leq 0.05)$.

${ }^{1} \mathrm{ORD}=100 \%$ orchardgrass; MIL $=50 \%$ orchardgrass $+50 \%$ Japanese millet; SSG $=50 \%$ orchardgrass + $50 \%$ sorghum $\times$ sudangrass; MIX $=50 \%$ orchardgrass $+25 \%$ Japanese millet $+25 \%$ sorghum $\times$ sudangrass.

(Muldoon, 1985; Darby et al., 2016) and were similar to the results of the current study. Apparent NDF digestibility was similar to that in previous studies using pure sorghum $\times$ sudangrass and Japanese millet (Ketterings et al., 2005; Darby et al., 2016). However, data on true digestibility of DM or OM for warm-season annuals are lacking in the literature.

\section{Fermentor $\mathrm{pH}, \mathrm{VFA}$, and $\mathrm{CH}_{4}$ Output}

There was no effect $(P \geq 0.23)$ of treatment on mean (of the data points collected), maximum, or minimum fermentor $\mathrm{pH}(6.76,6.89$, and 6.61, respectively; Table 3). Mean, maximum, and minimum $\mathrm{pH}$ for ORD were similar to previous continuous culture studies (Kolver et al., 1998; Bargo et al., 2003; Soder et al., 2012). Kolver and de Veth (2002) predicted that the mean $\mathrm{pH}$ for optimal pasture digestion was 6.35 , lower than all treatments in the current study; however, they also reported that nutrient digestion and synthesis of microbial protein were largely insensitive to $\mathrm{pH}$ across a broad range of $\mathrm{pH}$ values (5.8 to 6.8 ). It must be noted that the $\mathrm{pH}$ (mean, minimum, maximum) results of this study are reflective of the 4 data points measured immediately before each feeding, which may not be representative of diurnal changes in $\mathrm{pH}$. However, these data still provide valid information about mean $\mathrm{pH}$ and fluctuations in $\mathrm{pH}$ as affected by treatments.

Concentrations of total VFA were greater $(P=0.04)$ in SSG than in ORD (Table 3), with MIL and MIX having intermediary values. Total VFA concentrations observed in the current study were similar to values reported for cool-season perennial grasses in continuous culture (Bargo et al., 2003; Soder et al., 2012). Furthermore, no effect $(P \geq 0.40)$ of treatment was observed in molar proportions of valerate or isovalerate (1.90 and $0.05 \mathrm{~mol} / 100 \mathrm{~mol}$, respectively). Molar proportions of acetate were greater $(P \leq 0.01)$ in ORD and MIL than in SSG and MIX. Conversely, butyrate was lower $(P \leq$ $0.01)$ in ORD and MIL than in SSG and MIX, likely due to the increase of NFC in SSG and MIX compared with ORD, which agrees with data reported by Stokes et al. (1991) and Bach et al. (1999). Molar proportions of propionate were lower $(P \leq 0.01)$ in MIL than in SSG and MIX. The acetate to propionate ratio was greater $(P \leq 0.012)$ in ORD and MIL than in SSG. Furthermore, the acetate plus butyrate to propionate plus valerate ratio was greater $(P \leq 0.02)$ in MIL than in MIX and SSG, with ORD having an intermediate value. Acetate to propionate ratios in the current study were lower than those reported for cool-season grasses in continuous culture (Bach et al., 1999; Soder et al., 2012) but in agreement with other studies (Bargo et al., 2003; Wales et al., 2004). However, due to the elevated concentrations of butyrate, acetate plus butyrate to propionate ratios were similar to previously reported values for ORD (Soder et al., 2012). Differences in VFA ratios were likely due to lower WSC and ethanol-soluble carbohydrate in ORD and MIL than in SSG and MIX (Liu et al., 2009).

Methane output expressed as millimoles of $\mathrm{CH}_{4}$ per day was greatest $(P \leq 0.01)$ in MIL compared with all other treatments (Table 3). The $\mathrm{CH}_{4}$ output of SSG was lower $(P<0.03)$ than that of MIL. The same pattern was observed when $\mathrm{CH}_{4}$ output was expressed per gram of OM fed and per gram of NDF fed. However, when $\mathrm{CH}_{4}$ output was reported as $\mathrm{CH}_{4}$ per gram of NDF fed or digestible OM or NDF fed, we found no difference $(P \geq 0.11)$ between SSG and MIX treatments. Greater $\mathrm{CH}_{4}$ output in MIL was likely due to shifts in molar proportions of individual VFA. Although formation of propionate uses reducing equivalents, acetate and butyrate formation in the rumen produce $\mathrm{H}_{2}$ for methanogenesis (Hungate, 1966; Owens and Goetsch, 1988). The acetate to propionate ratio was greater in MIL than the other warm-season annual treatments 
(SSG and MIX) as discussed previously and, due to similar forage digestibility among treatments, this pattern was repeated when $\mathrm{CH}_{4}$ was calculated per gram of digestible $\mathrm{OM}$ and NDF fed.

There was no sampling time $\times$ treatment interaction $(P=0.39)$ for $\mathrm{CH}_{4}$ output variables (Figure 1$)$; however, we observed a significant effect $(P<0.01)$ of sampling time. Methane output was greater at 1000 $\mathrm{h}(P \leq 0.02)$ than at 0900 and $1530 \mathrm{~h}$ and tended $(P$ $=0.08)$ to be greater than at $0725 \mathrm{~h}(8.5,3.5,5.9,6.5$ mmol of $\mathrm{CH}_{4} / \mathrm{d}$, respectively). Methane samples taken at $0900 \mathrm{~h}$ had the lowest $(P \leq 0.04) \mathrm{CH}_{4}$ output (in mmol per day) of all sampling times. There was no difference $(P \geq 0.36)$ in $\mathrm{CH}_{4}$ output at 1000,1355 , or $1630 \mathrm{~h}$ (8.5, 7.7, and $7.5 \mathrm{mmol}$ of $\mathrm{CH}_{4} / \mathrm{d}$, respectively). Methane expressed based on OM, NDF, digestible OM, and digestible NDF fed showed the same diurnal fluctuation in $\mathrm{CH}_{4}$ production expressed in millimoles of $\mathrm{CH}_{4} /$ d. Methane output (mmol/d) displayed a diurnal variation throughout the day for all treatments, as shown previously (Hafla et al., 2014; Brask et al., 2015; Soder et al., 2016).

\section{Nitrogen Metabolism}

Treatment had no effect $(P=0.44)$ on $\mathrm{N}$ intake (averaging $2.30 \mathrm{~g}$ of $\mathrm{N} / \mathrm{d}$ across all treatments; Table 4). Concentration of $\mathrm{NH}_{3}-\mathrm{N}$ was $19 \%$ greater $(P<0.01)$ in ORD than in MIL and MIX; the concentration in SSG tended $(P=0.08)$ to be $10 \%$ lower than that in ORD. True CP digestibility was $10 \%$ greater $(P=0.02)$ in ORD than in MIL and tended $(P=0.07)$ to be $7 \%$ lower in MIX; conversely, SSG was not different $(P \geq$ 0.14 ) from any other treatment. Effluent total $\mathrm{N}$ and dietary $\mathrm{N}$ flows were lower $(P \leq 0.02)$ in ORD than in MIL (12 and 16\%, respectively), but MIL, SSG, and MIX were not different $(P \geq 0.16)$. We detected no difference $(P \geq 0.13)$ in bacterial $\mathrm{N}$ among treatments $(0.31 \mathrm{~g} / \mathrm{d})$. Concentrations of $\mathrm{NH}_{3}-\mathrm{N}$ in effluent were $19 \%$ greater $(P \leq 0.01)$ in ORD than in MIL or MIX. Effluent flow of NAN was $41 \%$ lower $(P \leq 0.02)$ in ORD than in all other treatments. Treatment did not affect $(P=0.29)$ bacterial efficiency when expressed as grams of bacterial N per kilogram of DM truly digested. Previous studies (Kolver et al., 1998; Soder et al., 2012) have reported similar values for concentrations of $\mathrm{NH}_{3}$ $\mathrm{N}$, total $\mathrm{N}$, and $\mathrm{NH}_{3}-\mathrm{N}$ effluent flows to that reported for ORD. True CP digestibility of ORD and SSG were 6 and 19\% greater, respectively, in the current study than in previous reports (Liu et al., 2009; Soder et al., 2012). Total effluent N, effluent NAN, and bacterial effluent $\mathrm{N}$ were at least half of what was reported in Soder et al. (2012), likely due to the greater true CP digestibility of treatments in the current study.

Bacterial efficiency expressed as grams of bacterial $\mathrm{N}$ per kilograms of truly digested OM was $44 \%$ greater $(P \leq 0.02)$ in MIL than in ORD (Table 4). Bacterial N efficiency per truly digestible OM was $83 \%$ greater in

Table 3. Fermentor $\mathrm{pH}$, VFA concentration and molar proportion, and $\mathrm{CH}_{4}$ output of orchardgrass and orchardgrass/warm-season annual mixtures during continuous culture fermentation

\begin{tabular}{|c|c|c|c|c|c|}
\hline \multirow[b]{2}{*}{ Item } & \multicolumn{4}{|c|}{ Treatment $^{1}$} & \multirow[b]{2}{*}{ SEM } \\
\hline & ORD & MIL & SSG & MIX & \\
\hline \multicolumn{6}{|l|}{$\mathrm{pH}$} \\
\hline Mean & 6.80 & 6.76 & 6.74 & 6.75 & 0.037 \\
\hline Minimum & 6.68 & 6.60 & 6.58 & 6.58 & 0.035 \\
\hline Maximum & 6.92 & 6.88 & 6.84 & 6.90 & 0.047 \\
\hline Total VFA, $\mathrm{m} M$ & $55.8^{\mathrm{a}}$ & $57.1^{\mathrm{ab}}$ & $59.2^{\mathrm{b}}$ & $57.9^{\mathrm{ab}}$ & 1.06 \\
\hline \multicolumn{6}{|l|}{ Individual VFA, mol/100 mol } \\
\hline Acetate (A) & $68.4^{\mathrm{a}}$ & $68.7^{\mathrm{a}}$ & $64.8^{\mathrm{b}}$ & $66.1^{\mathrm{b}}$ & 0.544 \\
\hline Propionate $(\mathrm{P})$ & $21.9^{\mathrm{ab}}$ & $21.1^{\mathrm{a}}$ & $23.2^{\mathrm{c}}$ & $22.8^{\mathrm{bc}}$ & 0.367 \\
\hline Butyrate (B) & $7.16^{\mathrm{a}}$ & $7.55^{\mathrm{a}}$ & $9.69^{\mathrm{b}}$ & $8.72^{\mathrm{b}}$ & 0.353 \\
\hline Isobutyrate & $0.58^{\mathrm{a}}$ & $0.45^{\mathrm{b}}$ & $0.49^{\mathrm{ab}}$ & $0.42^{\mathrm{b}}$ & 0.038 \\
\hline Valerate (V) & 1.78 & 1.99 & 1.81 & 2.02 & 0.115 \\
\hline Isovalerate & 0.12 & 0.08 & 0.00 & 0.00 & 0.071 \\
\hline $\mathrm{A}: \mathrm{P}$ & $3.12^{\mathrm{ab}}$ & $3.26^{\mathrm{a}}$ & $2.79^{\mathrm{c}}$ & $2.91^{\mathrm{bc}}$ & 0.074 \\
\hline $\mathrm{A}+\mathrm{B}: \mathrm{P}+\mathrm{V}$ & $3.19^{\mathrm{ab}}$ & $3.31^{\mathrm{a}}$ & $2.98^{\mathrm{b}}$ & $3.02^{\mathrm{b}}$ & 0.073 \\
\hline \multicolumn{6}{|l|}{$\mathrm{CH}_{4}$} \\
\hline $\mathrm{mmol}$ of $\mathrm{CH}_{4} / \mathrm{d}$ & $7.4^{\mathrm{a}}$ & $10.2^{\mathrm{b}}$ & $3.5^{\mathrm{c}}$ & $5.1^{\mathrm{c}}$ & 1.34 \\
\hline $\mathrm{mg}$ of $\mathrm{CH}_{4} / \mathrm{g}$ of $\mathrm{OM}$ fed & $2.13^{\mathrm{a}}$ & $2.96^{\mathrm{b}}$ & $1.01^{\mathrm{c}}$ & $1.49^{\mathrm{c}}$ & 0.388 \\
\hline $\mathrm{mg}$ of $\mathrm{CH}_{4} / \mathrm{g}$ of NDF fed & $3.36^{\mathrm{a}}$ & $5.02^{\mathrm{b}}$ & $1.66^{\mathrm{c}}$ & $2.48^{\mathrm{ac}}$ & 0.642 \\
\hline $\mathrm{mg}$ of $\mathrm{CH}_{4} / \mathrm{g}$ of digestible $\mathrm{OM}$ fed & $2.48^{\mathrm{a}}$ & $3.67^{\mathrm{b}}$ & $1.25^{\mathrm{c}}$ & $1.80^{\mathrm{ac}}$ & 0.453 \\
\hline $\mathrm{mg}$ of $\mathrm{CH}_{4} / \mathrm{g}$ of digestible NDF fed & $2.35^{\mathrm{a}}$ & $3.60^{\mathrm{b}}$ & $1.24^{\mathrm{c}}$ & $1.64^{\text {ac }}$ & 0.441 \\
\hline
\end{tabular}

${ }^{a-c}$ Within a row, means without a common superscript differ $(P \leq 0.05)$.

${ }^{1} \mathrm{ORD}=100 \%$ orchardgrass; $\mathrm{MIL}=50 \%$ orchardgrass $+50 \%$ Japanese millet; SSG $=50 \%$ orchardgrass + $50 \%$ sorghum $\times$ sudangrass; MIX $=50 \%$ orchardgrass $+25 \%$ Japanese millet $+25 \%$ sorghum $\times$ sudangrass. 
Table 4. Nitrogen metabolism of orchardgrass and orchardgrass/warm-season annual mixtures during continuous culture fermentation

\begin{tabular}{lccccc}
\hline & \multicolumn{4}{c}{ Treatment $^{1}$} \\
\cline { 2 - 4 } Item & ORD & MIL & SSG & MIX & SEM \\
\hline $\mathrm{N} \mathrm{intake,}^{2}$ g/d & 2.31 & 2.31 & 2.29 & 2.30 & 0.009 \\
$\mathrm{NH}_{3}-\mathrm{N}, \mathrm{mg} / \mathrm{dL}$ & $19.6^{\mathrm{a}}$ & $15.9^{\mathrm{b}}$ & $17.7^{\mathrm{ab}}$ & $15.9^{\mathrm{b}}$ & 0.71 \\
True CP digestibility, \% & $98.3^{\mathrm{a}}$ & $88.8^{\mathrm{b}}$ & $92.7^{\mathrm{ab}}$ & $91.4^{\mathrm{ab}}$ & 2.61 \\
$\mathrm{~N}$ flows, g/d & & & & & \\
Total N & $0.91^{\mathrm{a}}$ & $1.03^{\mathrm{b}}$ & $0.97^{\mathrm{ab}}$ & $0.99^{\mathrm{ab}}$ & 0.030 \\
$\mathrm{NH}_{3}-\mathrm{N}$ & $0.63^{\mathrm{a}}$ & $0.51^{\mathrm{b}}$ & $0.55^{\mathrm{ab}}$ & $0.51^{\mathrm{b}}$ & 0.027 \\
$\mathrm{NAN}$ & $0.28^{\mathrm{a}}$ & $0.52^{\mathrm{b}}$ & $0.42^{\mathrm{b}}$ & $0.48^{\mathrm{b}}$ & 0.046 \\
Bacterial N & 0.25 & 0.33 & 0.30 & 0.34 & 0.035 \\
Dietary N & $0.03^{\mathrm{a}}$ & $0.19^{\mathrm{b}}$ & $0.12^{\mathrm{ab}}$ & $0.15^{\mathrm{ab}}$ & 0.045 \\
Bacterial efficiency & & & & & \\
g of N/kg of DM truly digested & 6.23 & 7.85 & 7.00 & 7.58 & 0.596 \\
g of N/kg of OM truly digested & $5.95^{\mathrm{a}}$ & $8.57^{\mathrm{b}}$ & $7.44^{\mathrm{ab}}$ & $8.25^{\mathrm{ab}}$ & 0.814 \\
\hline
\end{tabular}

${ }^{\mathrm{a}, \mathrm{b}}$ Within a row, means without a common superscript differ $(P \leq 0.05)$.

${ }^{1} \mathrm{ORD}=100 \%$ orchardgrass; MIL $=50 \%$ orchardgrass $+50 \%$ Japanese millet; SSG $=50 \%$ orchardgrass + $50 \%$ sorghum $\times$ sudangrass; MIX $=50 \%$ orchardgrass $+25 \%$ Japanese millet $+25 \%$ sorghum $\times$ sudangrass.

${ }^{2} \mathrm{~N}$ intake $(\mathrm{g} / \mathrm{d})=\operatorname{dietary} \mathrm{N}(\mathrm{g} / \mathrm{d})+$ urea- $\mathrm{N}$ from buffer $(\mathrm{g} / \mathrm{d})$.

the current study than in Soder et al. (2012), but was $74 \%$ less than reported by Bargo et al. (2003), both of which reported numerically greater treatment $\mathrm{CP}$ concentrations (19.9 and $25.3 \%$, respectively) than the current study. Previous studies (Brito and Broderick, 2006; Soder et al., 2012) demonstrated that ruminal $\mathrm{NH}_{3}-\mathrm{N}$ concentrations below 5 to $8.5 \mathrm{mg}$ of $\mathrm{N} / \mathrm{dL}$ can depress bacterial $\mathrm{N}$ synthesis; however, because $\mathrm{NH}_{3}-\mathrm{N}$ was not a limiting factor in any treatment in the current study, this likely explains the lack of biologically significant differences among treatments.
Pearson correlation coefficients showed positive relationships $(P \leq 0.02$; Table 5$)$ between $\mathrm{CP}$ and $\mathrm{NH}_{3}-\mathrm{N}$, true $\mathrm{CP}$ digestibility, and effluent $\mathrm{NH}_{3}-\mathrm{N}$, but negative relationships $(P \leq 0.03)$ between $\mathrm{CP}$ and total effluent $\mathrm{N}$, effluent NAN, effluent dietary $\mathrm{N}$, and bacterial $\mathrm{N}$ efficiency per true OM digestibility across all treatments. Furthermore, there was no correlation $(P \geq 0.37)$ between degradable or soluble protein of treatments and any of the N metabolism variables. Devant et al. (2000) showed that degradability of $\mathrm{CP}$ in the rumen affects $\mathrm{N}$ digestibility and retention; however, in the current

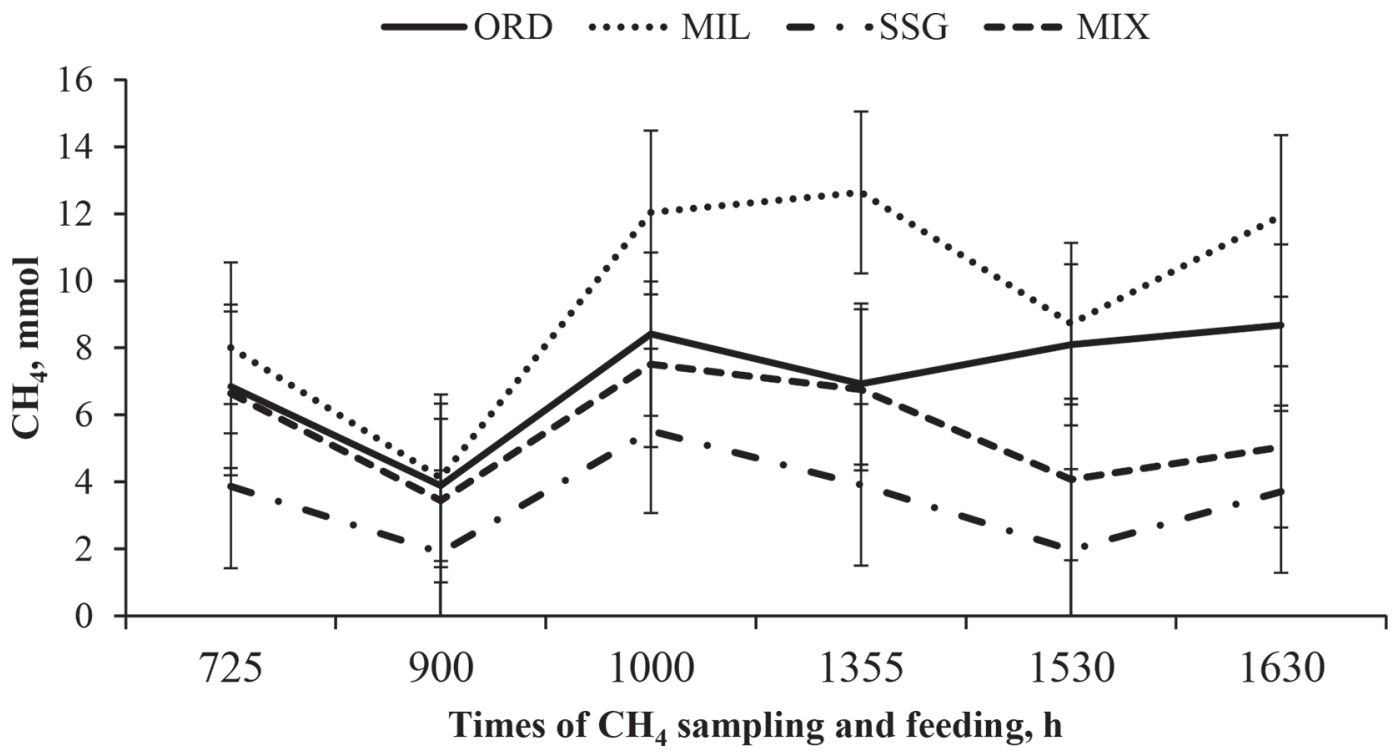

Figure 1. Temporal $\mathrm{CH}_{4}$ output of orchardgrass and orchardgrass/warm-season annual mixtures during continuous culture fermentation. All fermentors were fed orchardgrass at 0730 and $1000 \mathrm{~h}$, and orchardgrass (ORD), Japanese millet (MIL), sorghum × sudangrass (SSG), or a 50:50 mixture of Japanese millet and sorghum $\times$ sudangrass $(\mathrm{MIX})$ were fed at 1400 and $1900 \mathrm{~h} . \mathrm{CH}_{4}$ output $(\mathrm{mmol} / \mathrm{d})=\mathrm{mmol}$ of $\mathrm{CH} / \mathrm{mL} \times$ $20 \mathrm{~mL}$ of $\mathrm{CO}_{2} / \mathrm{min} \times 60 \mathrm{~min} / \mathrm{h} \times 24 \mathrm{~h} / \mathrm{d}$. Error bars represent $\mathrm{SE}$. 
Table 5. Correlation coefficients (r) between $\mathrm{CP}$ and $\mathrm{N}$ metabolism variables of orchardgrass and orchardgrass/warm-season annual mixtures during continuous culture fermentation

\begin{tabular}{lcr}
\hline Item & $\mathrm{r}$ & $P$-value \\
\hline $\mathrm{N}$ intake & 0.1992 & 0.46 \\
$\mathrm{NH}_{3}-\mathrm{N}$ & 0.6906 & $<0.01$ \\
True CP digestibility & 0.5563 & 0.02 \\
$\mathrm{~N}$ flows & & \\
Total N & -0.5608 & 0.02 \\
$\mathrm{NH}_{3}-\mathrm{N}$ & 0.6680 & $<0.01$ \\
$\mathrm{NAN}$ & -0.6900 & $<0.01$ \\
Bacterial N & -0.4187 & 0.01 \\
Dietary N & -0.5553 & 0.02 \\
Bacterial efficiency & & \\
$\mathrm{N} / \mathrm{DM}$ truly digested & -0.4490 & 0.08 \\
$\mathrm{~N} /$ OM truly digested & -0.5331 & 0.03 \\
\hline
\end{tabular}

study, the lack of biological differences in RDP among treatments was likely why no significant correlation was observed. Additionally, for all $\mathrm{N}$ metabolism traits, with the exceptions of total $\mathrm{N}$ intake and effluent $\mathrm{NH}_{3}$ $\mathrm{N}$ flow, only NDF entered the stepwise regression model $(P \leq 0.04)$. Neutral detergent fiber explained between 21.4 and $58.1 \%$ of the variability among treatments for each $\mathrm{N}$ metabolism variable. Microbial protein degradation is largely affected by the presence and type of carbohydrate in the feedstuff and typically results in greater $\mathrm{N}$ utilization with increasing amounts of readily digestible fiber (NDF) in the diet (Bach et al., 2005). In the current study, ADF of all treatments was greater than that reported by Bach et al. (2005), despite treatment NDF concentrations being similar.

\section{CONCLUSIONS}

Warm-season annuals provide a productive grazing alternative to cool-season grass pastures during the summer months. Although orchardgrass had slightly greater nutrient digestibility than the warm-season annuals (millet and BMR sorghum-sudangrass), the warmseason annuals showed benefits in bacterial efficiency. Results were mixed for $\mathrm{CH}_{4}$ output, with millet having the highest $\mathrm{CH}_{4}$ output and sorghum-sudangrass (and the mix of the 2 warm-season species) having the lowest $\mathrm{CH}_{4}$ output. It is important to note that forage quality of perennial cool-season grass pastures would likely be lower than that used in this study due to mid-summer heat and drought stress. This would make warm-season annuals even more valuable in grazing-based dairy systems as an alternative mid-summer forage. Additional research is needed to fully assess the potential of using warm-season annuals in the diets of lactating dairy cattle during the summer months to evaluate animal productivity and economics while grazing these forages.

\section{ACKNOWLEDGMENTS}

The authors thank J. Everhart, R. Stout, C. Dell (all of USDA-ARS Pasture Systems and Watershed Management Research Unit), and J. Dillon (Pennsylvania State University) for laboratory expertise and time contributed to conducting this experiment. This project was partially funded by USDA National Institute of Food and Agriculture Organic Agriculture Research and Extension Initiative (Washington, DC).

\section{REFERENCES}

AOAC International. 2006. Official Methods of Analysis. 18th ed. AOAC International, Gaithersburg, MD.

Bach, A., S. Calsamiglia, and M. D. Stern. 2005. Nitrogen metabolism in the rumen. J. Dairy Sci. 88(E. Suppl.):E9-E21. https://doi. org/10.3168/jds.S0022-0302(05)73133-7.

Bach, A., I. K. Yoon, M. D. Stern, H. G. Jung, and H. Chester-Jones. 1999. Effects of type of carbohydrate supplementation to lush pastures on microbial fermentation in continuous culture. J. Dairy Sci. 82:153-160. https://doi.org/10.3168/jds.S0022-0302(99)75219-7.

Bargo, F., G. A. Varga, L. D. Muller, and E. S. Kolver. 2003. Pasture intake and substitution rate effects on nutrient digestion and nitrogen metabolism during continuous culture fermentation. J. Dairy Sci. 86:1330-1340. https://doi.org/10.3168/jds.S00220302(03)73718-7.

Brask, M., M. R. Weisbjerg, A. L. F. Hellwing, A. Bannink, and P. Lund. 2015. Methane production and diurnal variation measured in dairy cows and predicted from fermentation pattern and nutrient or carbon flow. Animal 9:1795-1806. https://doi.org/10.1017/ S1751731115001184.

Brito, A. F., and G. A. Broderick. 2006. Effect of varying dietary ratios of alfalfa silage to corn silage on production and nitrogen utilization in lactating dairy cows. J. Dairy Sci. 89:3924-3938. https:// doi.org/10.3168/jds.S0022-0302(06)72435-3.

Chaney, A. L., and E. P. Marbach. 1962. Modified reagents for determination of urea and ammonia. Clin. Chem. 8:130-132.

Clark, N. A., R. W. Hemken, and J. H. Vandersall. 1965. A comparison of pearl millet, sudangrass and sorghum-sudangrass hybrid as pasture for lactating dairy cows. Agron. J. 57:266-269.

Coblentz, W. K., I. E. O. Abelgardir, R. C. Cochran, J. O. Fritz, W. H. Fick, K. C. Olson, and J. E. Turner. 1999. Degradability of forage proteins by in situ and in vitro enzymatic methods. J. Dairy Sci. 82:343-354. https://doi.org/10.3168/jds.S0022-0302(99)75241-0.

Cowan, R. T., and K. F. Lowe. 1998. Tropical and subtropical grass management and quality. Pages 101-135 in Grass for Dairy Cattle. J. H. Cherney and D. J. R. Cherney, ed. CABI Publishing, New York, NY.

Darby, H., S. Ziegler, L. Calderwood, E. Cummings, A. Gupta, and J. Post. 2016. 2015 Summer annual variety trial. University of Vermont Extension. Accessed Mar. 25, 2016. http://www.uvm. edu/extension/cropsoil/wp-content/uploads/2015-SummerAnnual-VT.pdf.

Devant, M., A. Ferret, J. Gasa, S. Calsamiglia, and R. Casals. 2000 Effects of protein concentration and degradability on performance, ruminal fermentation, and nitrogen metabolism in rapidly growing heifers fed high-concentrate diets from 100 to $230 \mathrm{~kg}$ body weight. J. Anim. Sci. 78:1667-1676.

Erwin, E. S., G. J. Marco, and E. M. Emery. 1961. Volatile fatty acid analysis of blood and rumen fluid by gas chromatography. J. Dairy Sci. 44:1768-1771.

Fontaneli, R. S., L. E. Sollenberger, and C. R. Staples. 2001. Yield, yield distribution, and nutritive value of intensively managed warm-season annual grasses. Agron. J. 93:1257-1262. https://doi. org/10.2134/agronj2001.1257. 
Griswold, K. E., W. H. Hoover, T. K. Miller, and W. V. Thayne. 1996. Effect of form of nitrogen on ruminal microbes in continuous culture. J. Anim. Sci. 74:483-491.

Hafla, A. N., K. J. Soder, A. F. Brito, R. Kersbergen, F. Benson, H. Darby, M. D. Rubano, and S. F. Reis. 2016. Case Study: Feeding strategy and pasture quality relative to nutrient requirements of dairy cows in the northeastern United States. Prof. Anim. Sci. $32: 523-530$.

Hafla, A. N., K. J. Soder, A. F. Brito, M. D. Rubano, and C. J. Dell. 2014. Effect of sprouted barley grain supplementation of an herbage-based or haylage-based diet on ruminal fermentation and methane output in continuous culture. J. Dairy Sci. 97:7856-7869. https://doi.org/10.3168/jds.2014-8518.

Hall, M. B., W. H. Hoover, J. P. Jennings, and T. K. Miller-Webster. 1999. A method for partitioning neutral detergent-soluble carbohydrates. J. Sci. Food Agric. 79:2079-2086.

Hodgson, J., J. M. Rodriguez Capriles, and J. S. Fenlon. 1977. The influence of sward characteristics on the herbage intake of grazing calves. J. Agric. Sci. (Camb.) 89:743-750. https://doi.org/10.1017/ S0021859600061542.

Hoffman, K., R. DeClue, and D. L. Emmick. 2000. Prescribed grazing and feeding management for lactating dairy cows. New York State Grazing Lands Conservation Initiative, Syracuse, NY.

Hoover, W. H., B. A. Crooker, and C. J. Sniffen. 1976. Effects of differential solid-liquid removal rates on protozoa numbers in continuous cultures of rumen contents. J. Anim. Sci. 43:528-534. https:// doi.org/10.2527/jas1976.432528x.

Hoover, W. H., T. K. Miller, S. R. Stokes, and W. V. Thayne. 1989. Effects of fish meals on rumen bacterial fermentation in continuous culture. J. Dairy Sci. 72:2991-2998. https://doi.org/10.3168/jds. S0022-0302(89)79451-0.

Hungate, R. E. 1966. The Rumen and its Microbes. Academic Press, New York, NY.

Johnson, M. C., A. A. Devine, J. C. Ellis, A. M. Grunden, and V. Fellner. 2009. Effects of antibiotics and oil on microbial profiles and fermentation in mixed cultures of ruminal microorganisms. J. Dairy Sci. 92:4467-4480. https://doi.org/10.3168/jds.2008-1841.

Jones, D. I. H., and R. W. Bailey. 1972. The hydrolysis of cell wall polysaccharides from freeze- dried and oven-dried herbage by rumen and mould carbohydrases. J. Sci. Food Agric. 23:609-614. https://doi.org/10.1002/jsfa.2740230509.

Ketterings, Q. M., G. Godwin, J. H. Cherny, and T. F. Kilcer. 2005. Potassium management for brown midrib sorghum $\times$ sudangrass as replacement for corn silage in the Northeastern USA. J. Agro. Crop Sci. 191:41-46. https://doi.org/10.1111/j.1439037X.2004.00144.x.

Kolver, E. S., and M. J. de Veth. 2002. Prediction of ruminal pH from pasture-based diets. J. Dairy Sci. 85:1255-1266. https://doi. org/10.3168/jds.S0022-0302(02)74190-8.

Kolver, E. S., L. D. Muller, G. A. Varga, and T. J. Cassidy. 1998. Synchronization of ruminal degradation of supplemental carbohydrate with pasture nitrogen in lactating dairy cows. J. Dairy Sci. 81:2017-2028. https://doi.org/10.3168/jds.S00220302(98)75776-5.

Liu, Q., C. S. Dong, H. Q. Li, W. Z. Yang, J. B. Jiang, W. J. Gao, C. X. Pei, and J. J. Qiao. 2009. Effects of feeding sorghum-sudan, alfalfa hay and fresh alfalfa with concentrate on intake, first compartment stomach characteristics, digestibility, nitrogen balance and energy metabolism in alpacas (Lama pacos) at low altitude. Livest. Sci. 126:21-27. https://doi.org/10.1016/j.livsci.2009.05.013.

Mertens, D. R. 2002. Gravimetric determination of amylase-treated neutral detergent fiber in feeds with refluxing in beakers or crucibles: Collaborative study. J. AOAC Int. 85:1217-1240.
Miller-Webster, T., W. H. Hoover, M. Holt, and J. E. Nocek. 2002. Influence of yeast culture on ruminal microbial metabolism in continuous culture. J. Dairy Sci. 85:2009-2014. https://doi.org/10.3168/ jds.S0022-0302(02)74277-X.

Muldoon, D. K. 1985. Summer forages under irrigation 2. Forage composition. Aust. J. Exp. Agric. 25:402-410. https://doi. org $/ 10.1071 /$ EA9850402.

NRC. 2001. Nutrient Requirements of Dairy Cattle. 7th rev. ed. Natl. Acad. Press, Washington, D.C.

Owens, F. N., and A. L. Goetsch. 1988. Ruminal fermentation. Pages 145-171 in The Ruminant Animal: Digestive Physiology and Metabolism. Prentice Hall, NJ.

Pereira, A. B. D., A. F. Brito, L. L. Townson, and D. H. Townson. 2013. Assessing the research and education needs of the organic dairy industry in the northeastern United States. J. Dairy Sci. 96:7340-7348. https://doi.org/10.3168/jds.2013-6690.

Smith, D. 1969. Removing and analyzing total nonstructural carbohydrates from plate tissue. Wisconsin Agric. Exp. Sta. Res. Rep. 41:1.

Soder, K. J., A. F. Brito, and M. D. Rubano. 2012. Effect of incremental flaxseed supplementation of an herbage diet on methane output and ruminal fermentation in continuous culture. J. Dairy Sci. 95:3961-3969. https://doi.org/10.3168/jds.2011-4981.

Soder, K. J., A. F. Brito, A. N. Hafla, and M. D. Rubano. 2016. Effect of starchy or fibrous carbohydrate supplementation of orchardgrass on ruminal fermentation and methane output in continuous culture. J. Dairy Sci. 99:4464-4475. https://doi.org/10.3168/ jds.2015-10471.

Stiglbauer, K. E., K. M. Cicconi-Hogan, R. Richert, Y. H. Schukken, P. L. Ruegg, and M. Gamroth. 2013. Assessment of herd management on organic and conventional dairy farms in the United States. J. Dairy Sci. 96:1290-1300. https://doi.org/10.3168/ jds.2012-5845.

Stokes, S. R., W. H. Hoover, T. K. Miller, and R. P. Manski. 1991. Impact of carbohydrate and protein levels on bacterial metabolism in continuous culture. J. Dairy Sci. 74:860-870. https://doi. org/10.3168/jds.S0022-0302(91)78235-0.

Vibart, R. W., S. P. Washburn, V. Fellner, M. H. Poore, J. T. Green Jr., and C. Brownies. 2007. Varying endophyte status and energy supplementation of fresh tall fescue in continuous culture. Anim. Feed Sci. Technol. 132:123-136. https://doi.org/10.1016/j. anifeedsci.2006.03.002.

Wales, W. J., E. S. Kolver, P. L. Thorne, and A. R. Egan. 2004. Diurnal variation in ruminal $\mathrm{pH}$ on the digestibility of highly digestible perennial ryegrass during continuous culture fermentation. J. Dairy Sci. 87:1864-1871. https://doi.org/10.3168/jds. S0022.0302(04)73344-5.

Weller, R. A., and A. F. Pilgrim. 1974. Passage of protozoa and volatile fatty acids from the rumen of the sheep and from a continuous in vitro fermentation system. Br. J. Nutr. 32:341-351.

Winsten, J. R., C. D. Kerchner, A. Richardson, A. Lichau, and J. M. Hyman. 2010. Trends in the Northeast dairy industry: large-scale modern confinement feeding and management-intensive grazing. J. Dairy Sci. 93:1759-1769. https://doi.org/10.3168/jds.2008-1831.

Wolfe, D. W., L. Ziska, C. Petzoldt, A. Seaman, L. Chase, and K. Hayhoe. 2008. Projected change in climate thresholds in the Northeastern U.S.: Implications for crops, pests, livestock, and farmers. Mitig. Adapt. Strategies Glob. Change 13:555-575. https://doi. org/10.1007/s11027-007-9125-2.

Zinn, R. A., and F. N. Owens. 1986. A rapid procedure for purine measurement and its use for estimating net ruminal protein synthesis. Can. J. Anim. Sci. 66:157-166. https://doi.org/10.4141/ cjas2013-158. 